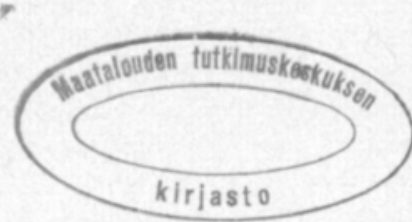

\title{
Nurmisäilörehukokeita maatilasiiloissa 1. Rehuarvon muutokset ja säilöntätappiot
}

\author{
Maija-Lissa Salo ja Rirtta Sormunen \\ Helsingin yliopiston kotieläintieteen laitos, 00710 Helsinki

\section{Investigations of grass silage prepared in ordinary farm conditions 1. Changes in nutritive value and preservation losses}

\author{
Maija-Liisa Salo and Rittra Sormunen \\ Department of Animal Husbandry, University of Helsinki, 00710 Helsinki
}

\begin{abstract}
The changes in nutritive value and preservation losses occurring when grass is ensiled in ordinary farm conditions were investigated on the Viik Experimental Farm in the years $1970-1973$. The grass was ensiled in four 9-m-high concrete silos with volumes of $118-346 \mathrm{~m}^{3}$. The grass of the first and second cutting was from pasture and silage swards, that of the third from the aftermath of the ley or the third growth of the silage swards. Meadow fescue and timothy were the dominant plant species. The grass was wilted when the weather allowed, the wilting time varying from $4 \mathrm{~h}$ to $4 \frac{1}{2}$ days. The DM content of the wilted grass ranged from $14 \%$ (rain-soaked) to $76 \%$. Formic acid was added, $0-0.15 \%$ to the wilted grass, and $0.30 \%$ to the rain-soaked wilted and fresh grass. The silos were filled up one at time regardless of the weather. A great deal of the third cutting grass was placed upon the earlier silage, with sheets of plastic between.

On the various cutting days known amounts of grass were enclosed in sack and put in the silos (total 65 sacks of wilted and 22 sacks of fresh grass). The chemical composition and in vitro digestibility were determined on samples from the sacks. The metabolizable energy value (ME) was calculated on the basis of $\mathrm{D}$ value and the content of crude protein (CP).

The preservation losses and decrease in ME were significantly smaller in the silages made from wilted grass. When the sacks were grouped as follows: 1) harvested in rain, 2) exposed to strong flow of effluent from above, 3) ensiled without additive 4) the rest, the preservation losses and decrease in ME were higher in groups $1-2$ than in $3-4(\mathrm{P}<0.01-0.001)$. The effluent had a worse effect than harvesting in rain.

High DM losses decreased the energy value of silage but not the CP content, because the DM and CP losses were nearly equal. The average decrease in the in vitro digestibility of OM during ensilage was $3.7 \%$ and that in ME $3.5 \%$. Poor quality was associated with great losses.

The grass and silage from the first cutting had the best digestibility and ME value. Fermentation was stronger in the first cutting silage than in that of the third cutting $(\mathrm{P}<0.001)$, although the latter had a higher moisture content.
\end{abstract}


Comparison of the results of different years showed that the moisture content of the grass and the weather at the cutting time were most important factors.

Close correlations were observed between the various components of the grass and silage and between various preservation losses.

The variation of the results was much greater than for silage prepared under controlled experimental conditions. The DM losses were under $5 \%$ in one third of the samples and over $25 \%$ in ten per cent. The worst faults in ensiling were as follows: 1) The silo was filled up regardless of the weather, so that wilted, fresh and even rain-soaked wilted grass could come in alternate layers. 2) In the autumn fresh grass or sugar beet tops were placed upon the earlier silage. The sheets of plastic did not prevent the effluent from flowing down into the silage. On the other hand, good results were obtained even with wet grass, if it was placed on the bottom of the silo and covered with grass that was so well wilted that no effluent flowed from it.

\section{Johdanto}

Säilörehun valmistuksessa on kuljettu alkuperäisestä painorehusta vahvojen happojen eli ns. AIV-menetelmän kautta orgaanisiin happoihin ja bakteerisidisiin säilöntäaineisiin. Lisäaineiden vaihtoehtona tai täydennyksenä on viime vuosikymmeninä käytetty ruohon esikuivaamista pellolla. Säilöntäkokeiden tuloksia on esitelty monissa katsauksissa (HAGEMEISTER 1967, MASKova ja Havelik 1969, Gross ja Riebe 1974). Myös Suomessa on viime vuosina suoritettu laajoja säilörehukokeita (Poutiainen ja Rinne 1971, Ettala ym. 1971, 1972, 1975).

Tällä tutkimuksella pyrittiin selvittelemään säilönnän aikana tapahtuvia rehuarvon muutoksia ja säilöntätappioita käytännön säilörehun valmistuksessa. Säilörehu valmistettiin maatilan ohjelman mukaisesti eli ruohoa esikuivattiin aina kun sää sen salli, säilöntäainetta käytettiin säästeliäästi ja ruoho säilöttiin suuriin tornisiiloihin. Mukaan pantiin päivittäin koesäkkejä, joissa oli tietty määrä rehua. Kokeet suoritettiin Viikin koetilalla vuosina $1970-1973$.

\section{Kokeiden suoritus}

Säilörehu tehtiin neljään betonisiiloon, joiden korkeus oli $9 \mathrm{~m}$ ja tilavuus $118,161,161$ ja $346 \mathrm{~m}^{2}$. 1. ja 2. korjuukerran ruoho oli laidun- ja säilörehunurmilta, joissa valtakasvina oli nurminata tai timotei. 3. korjuukerran ruoho oli pääosaltaan niittonurmen odelmaa, valtakasvina timotei ja osassa vähän apilaa, sekä pieni osa säilörehunurmien 3. satoa. Typpeä oli käytetty korjuukertaa kohti laitumille ja säilörehunurmille noin $70 \mathrm{~kg} \mathrm{~N} / \mathrm{ha}$ ja niittonurmen odelmalle noin $100 \mathrm{~kg} \mathrm{~N} / \mathrm{ha}$. 1. korjuu aloitettiin ennen kuin röyhy tai tähkä oli näkyvissä ja korjuuaika kesti säästä riippuen $4-9$ pv. Toinen korjuu tapahtui heinä-elokuun vaihteessa ja kolmas syyskuulla.

Ruohoa esikuivattiin aina kun sää sen salli, kuivausaika vaihteli 4 tunnista $4 \frac{1}{2}$ vuorokauteen ja esikuivatun ruohon ka-pitoisuus $14 \%$ :sta (sateen kastelema) $76 \%$ :iin. Esikuivattu ruoho silputtiin tarkkuussilppurilla ja muurahaishappoa lisättiin $0-0.15 \%$, sateen kastelemaan $0.30 \%$. Pieni osa 1 . korjuun ruohosta ja kolmena vuonna koko syksysato korjattiin niittotuoreena, ka-pitoisuus oli 13-25\%. Korjuu suoritettiin kelasilppurilla ja muurahais- 
happoa lisättiin $0.30 \%$. Siilot täytettiin yksi kerrallaan sateesta riippumatta. Rehu peitettiin saumaamattomalla muovikalvolla ja painotettiin noin 200 $\mathrm{kg} / \mathrm{m}^{2}$. Suuri osa kolmannen korjuukerran ruohosta pantiin entisen rehun päälle, muovikalvo jätettiin väliin.

Koesäkkejä pantiin siiloihin lähes joka korjuupäivä. Säkkeihin punnittiin ruohoa ka-pitoisuudesta riippuen 5-15 kg ja säkkejä sijoitettiin kahtena rinnakkaisena kautta siilon. Koesäkkien lukumäärä ja esikuivattujen ja niittotuoreiden osuus käy ilmi taulukosta 1.

Taulukko 1. Esikuivattujen ja niittotuoreiden koesäkkien määrä eri vuosina.

Table 1. The number of experimental sacks in the various years.

\begin{tabular}{|c|c|c|c|c|}
\hline \multirow[t]{2}{*}{$\begin{array}{l}\text { Vuosi } \\
\text { Year }\end{array}$} & \multicolumn{2}{|c|}{$\begin{array}{c}\text { Esikuivattuja } \\
\text { Wilted }\end{array}$} & \multicolumn{2}{|c|}{$\begin{array}{c}\text { Niittotuoreita } \\
\text { Fresh }\end{array}$} \\
\hline & $\mathrm{n}$ & $\%$ & $\mathrm{n}$ & $\%$ \\
\hline 1970 & 15 & 65.2 & 8 & 34.8 \\
\hline 1971 & 10 & 62.5 & 6 & 37.5 \\
\hline 1972 & 25 & 92.6 & 2 & 7.4 \\
\hline 1973 & 15 & 71.4 & 6 & 28.6 \\
\hline $\begin{array}{l}\text { Yhteensä } \\
\text { Total }\end{array}$ & 65 & 74.7 & 22 & 25.3 \\
\hline
\end{tabular}

Säkkeihin tulevasta ruohosta määritettiin ka-pitoisuus $100^{\circ} \mathrm{C}: s s a ̈$ ja kuivattiin analyysinäyte $40-50^{\circ} \mathrm{C}$ :ssa vakuumissa. Koesäkit punnittiin sitä mukaa kuin niitä ruokintakauden aikana tuli esiin siiloista. Säilörehusta määritettiin ka-pitoisuus, $\mathrm{pH}, \mathrm{NH}_{3}-\mathrm{N}$ ja orgaaniset hapot sekä kuivattiin analyysinäyte kuten ruohosta. Haihtuvien happojen osuutta ei huomioitu tappioita laskettaessa.

Muut analyysit tehtiin kuivatusta näytteestä. Virallisen rehuanalyysin määritykset suoritettiin standardimenetelmillä. Sokerit ja orgaaniset hapot määritettiin SALOn $(1965,1969)$ menetelmillä. Happojen ekvivalenttimäärää painomääräksi muunnettaessa ruohojen hapot laskettiin omenahappona ja säilörehujen seoksena, jossa maitohappoa on $75 \%$ ja etikkahappoa $25 \%$. In vitro-sulavuus määritettiin TILLEYn ja TERRY (1963) menetelmällä ja $\mathrm{NH}_{3}-\mathrm{N}$ tavanomaisella tislausmenetelmällä (A. O. A. C. 1960, s. 832). Muuntokelpoisen energian arvo (Mcal. ME/kg ka) laskettiin TERRYn ym. (1974) kaavalla, mikä perustuu in vitro-sulavan orgaanisen aineen (D-arvo) ja raakaproteiinin pitoisuuteen. Tulosten tilastollinen käsittely suoritettiin Helsingin yliopiston laskentakeskuksessa.

\section{Tulokset}

Taulukkojen luvut kuvaavat varsin hyvin säilörehun raaka-aineen ja säilörehun rehuarvoa Viikin koetilalla vuosina 1970-1973, koska koesäkkejä pantiin siiloihin lähes jokaisena säilörehun tekopäivänä. Niistä selviää myös 
säilöntätappiot lukuunottamatta esikuivatustappioita pellolla ja pintapilaantumista, mitkä jäivät tutkimuksen ulkopuolelle.

\section{Ruohon koostumus siiloon pantaessa}

Korju ukerran vaikutus Ruoho oli sulavuudeltaan ja MEarvoltaan parasta 1. korjuukertana siitä huolimatta, että se vuosina 1970 ja 1973 oli viimeisinä korjuupäivinä korjuuajalle sattuneen hellekauden johdosta täydellä tähkällä (taulukko 2). Heikoin energia-arvo oli 2. korjuukerran ja heikoin proteiinipitoisuus 3. korjuukerran ruohossa. Suurin hajonta näytteiden välillä oli 3. korjuukaudella johtuen siitä, että osa näytteistä oli mehevää niittonurmen odelmaa, osa korsiintunutta säilörehunurmen 3. satoa. Esikuivatustulos vaihteli paljon kaikkina korjuukertoina, keskimäärin kuivimpana siiloon saatiin 2. korjuukerran ruoho.

V u o d e n vai k u t u s. Vuosien väliset erot olivat huomattavasti vähäisemmät kuin korjuukertojen väliset ja taulukossa 3 esitetään sen vuoksi vain kaikkien neljän vuoden keskiarvo ja vuosien välinen hajonta. Rinnalla nähdään samojen ruohonäytteiden koostumus säilörehuna. Keskimäärin parasta

Taulukko 2. Ruohon koostumus (\% ka:sta) 1., 2. ja 3. korjuukertana.

Table 2. Chemical composition of grass ( $\%$ of DM) of 1 st, 2 nd and 3 rd cuttings.

\begin{tabular}{|c|c|c|c|c|c|c|c|c|c|c|}
\hline & \multicolumn{2}{|c|}{$\begin{array}{c}1 \\
\left(n^{2}=21\right)\end{array}$} & \multicolumn{2}{|c|}{$\begin{array}{c}2 \\
(n=11)\end{array}$} & \multicolumn{2}{|c|}{$\begin{array}{c}3 \\
(n=13)\end{array}$} & \multicolumn{3}{|c|}{$\begin{array}{l}\text { Merkitsevyys } \\
\text { Significance }^{1} \text { ) }\end{array}$} & \multirow{2}{*}{$\begin{array}{l}- \\
.001\end{array}$} \\
\hline & $\overline{\mathbf{x}}$ & $\mathrm{S}$ & $\overline{\mathbf{x}}$ & $\mathrm{s}$ & $\overline{\mathbf{x}}$ & $\mathrm{S}$ & NS & .05 & .01 & \\
\hline 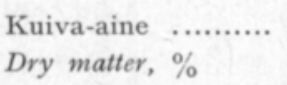 & 31.9 & 10.4 & 37.3 & 20.8 & 27.4 & 16.2 & $\mathrm{ABC}$ & & & \\
\hline $\begin{array}{l}\text { R. proteiini ........... } \\
\text { Crude protein }\end{array}$ & 19.8 & 3.0 & 19.9 & 1.0 & 17.2 & 3.5 & A & $\mathrm{BC}$ & & \\
\hline $\begin{array}{l}\text { R. kuitu ................... } \\
\text { Crude fibre }\end{array}$ & 23.7 & 2.2 & 26.1 & 2.3 & 23.0 & 3.7 & C & B & A & \\
\hline $\begin{array}{l}\text { Tuhka } \ldots . \cdots \cdots \cdots \cdots \\
\text { Ash }\end{array}$ & 9.8 & 1.1 & 9.6 & 1.1 & 9.8 & 2.3 & $\mathrm{ABC}$ & & & \\
\hline $\begin{array}{l}\text { Sokerit ...................... } \\
\text { Sugars }\end{array}$ & 10.1 & 2.8 & 6.6 & 1.9 & 12.1 & 2.7 & & C & & $\mathrm{AB}$ \\
\hline $\begin{array}{l}\text { Org. hapot ............ } \\
\text { Organic acids }\end{array}$ & 5.2 & 0.5 & 4.9 & 0.5 & 5.0 & 0.1 & $\mathrm{ABC}$ & & & \\
\hline 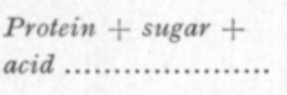 & 36.1 & 4.8 & 31.4 & 2.1 & 34.4 & 3.4 & C & B & A & \\
\hline $\begin{array}{l}\text { In vitro digestib. of } \\
\mathrm{OM}, \%\end{array}$ & 74.8 & 2.9 & 68.2 & 2.9 & 71.7 & 3.8 & & $\mathrm{BC}$ & & A \\
\hline $\begin{array}{l}\text { In vitro digestib. of } \\
\mathrm{DM}, \% \ldots \ldots . . . . . . . .\end{array}$ & 75.6 & 2.9 & 69.0 & 2.6 & 71.6 & 3.2 & & B & & AC \\
\hline Mcal. ME/kg ka DM & 2.65 & 0.14 & 2.46 & 0.12 & 2.51 & 0.17 & B & $\mathrm{C}$ & & A \\
\hline
\end{tabular}

1) $\mathrm{A}=1-2, \mathrm{~B}=2-3, \mathrm{C}=1-3$. 
rehuarvoltaan oli vuoden 1970 ruoho, heikointa vuosien 1972 ja 1973 . Ero vuosien välillä oli ME-arvossa ja proteiinipitoisuudessa suurimmillaankin tuskin merkitsevä $(\mathrm{P}<0.05)$. Sääoloiltaan vaikein oli vuosi 1972 , jolloin 1 . korjuun ajankohtaan osui pitkä sadekausi. Toisaalta samana vuonna korjattiin koko 3 . korjuukerran sato esikuivattuna $(45-63 \% \mathrm{ka})$, kun se muina vuosina korjattiin niittotuoreena. Esikuivattujen näytteiden osuus olikin v. 1972 korkein (taulukko 1), mutta monet esikuivatuista saivat sadetta.

\section{Säilörehun koostumus}

Korju ukerran vaikutus. Taulukossa 4 esitetään taulukon 2 ruohoja vastaavien säilörehujen koostumus ruokintavaiheessa eli noin $3-11$ kk:n säilöntäajan jälkeen. 1. korjuukerran ruoho oli myös säilörehuna sulavuudeltaan ja ME-arvoltaan muita parempaa $(\mathrm{P}<0.001)$ siitä huolimatta, että käyminen oli siinä muita voimakkaampaa. Runsas käyminen näkyy korkeana happopitoisuutena ja matalana sokeripitoisuutena $(\mathrm{P}<0.001)$. Käymistä hillitsi 2. korjuun rehussa ruohon korkea ka-pitoisuus ja 3 . korjuun rehussa syksyn viileä sää. $\mathrm{NH}_{3}$-typen osuus oli suurin 1 . korjuun rehussa, mutta hajonta oli niin suuri, ettei ero ollut merkitsevä.

V u oden vaikut us. Säilörehun rehuarvossa oli vuosien välillä suurempia eroja kuin sen raaka-aineessa (taulukko 3). Suhteellisesti eniten huononi säilöntäaikana koostumukseltaan parhaana, mutta muita kosteampana säilötty vuoden 1970 ruoho. Vuosien 1972 ja 1973 ruoho oli siiloon pantaessa rehuarvoltaan muita heikompaa ja keskenään jokseenkin samanveroista, mutta sadekesän 1972 ruohon arvo aleni säilöntäaikana enemmän kuin poutavuoden 1973. ME-arvon ja erikoisesti kuitupitoisuuden erot vuosien välillä saattoivat olla hyvin merkitseviä $(\mathrm{P}<0.01-0.001)$.

Taulukko 3. Ruohon ja vastaavan säilörehun koostumus (\% ka:sta) vuosina $1970-1973$ sekä vuosien välinen hajonta.

Table 3. Chemical composition of grass and corresponding silages (\% of DM) in the years 1970-1973, and the variation between years.

\begin{tabular}{|c|c|c|c|c|c|c|}
\hline & $\begin{array}{c}\text { Ruoho } \\
\overline{\mathbf{x}}\end{array}$ & $\begin{array}{c}\text { Grass } \\
\mathrm{S}\end{array}$ & $\begin{array}{c}=45) \\
F\end{array}$ & \multicolumn{3}{|c|}{ Säilörehut - Silages $(\mathrm{n}=87)$} \\
\hline Kuiva-aine - Dry matter, $\%$ & 31.9 & 15.2 & .01 & 32.6 & 12.3 & .01 \\
\hline R. proteiini - Crude protein & 19.1 & 3.2 & NS & 19.1 & 2.8 & NS \\
\hline R. kuitu - Crude fibre & 24.1 & 2.9 & .01 & 26.3 & 3.3 & .001 \\
\hline Tuhka $-A s h$ & 9.8 & 1.5 & .01 & 9.5 & 1.9 & .01 \\
\hline Sokerit - Sugars & 9.8 & 3.3 & NS & 3.3 & 3.1 & NS \\
\hline Org. hapot - Organic acids & 5.1 & 0.7 & NS & 12.2 & 3.2 & NS \\
\hline Protein + sugar + acid & 34.5 & 4.3 & .05 & 34.6 & 4.0 & .05 \\
\hline In vitro digestib. of $O M, \%$ & 72.4 & 4.1 & .05 & 69.7 & 4.2 & 0.5 \\
\hline$, \quad, \quad D M, \%$ & 72.9 & 4.0 & NS & 70.1 & 4.4 & NS \\
\hline Mcal. ME/kg ka $-D M$ & 2.57 & 0.16 & NS & 2.48 & 0.16 & .05 \\
\hline $\mathrm{pH}$ & & & & 4.2 & 0.5 & .01 \\
\hline $\mathrm{NH}_{3}-\mathrm{N}, \%$ of total $\mathrm{N}$ & & & & 5.5 & 5.5 & .05 \\
\hline
\end{tabular}


Taulukko 4. Säilörehun koostumus (\% ka:sta) ja laatu 1., 2. ja 3. korjuukertana.

Table 4. Chemical composition (\% of DM) and quality of silages of 1st, 2 nd and 3 rd cuttings.

\begin{tabular}{|c|c|c|c|c|c|c|c|c|c|c|}
\hline & \multicolumn{2}{|c|}{$\begin{array}{c}1 \\
(n=42)\end{array}$} & \multicolumn{2}{|c|}{$\begin{array}{c}2 \\
(n=20)\end{array}$} & \multicolumn{2}{|c|}{$\begin{array}{c}3 \\
(n=25)\end{array}$} & \multicolumn{4}{|c|}{$\begin{array}{c}\text { Merkitsevyys - } \\
\text { Significance }^{1} \text { ) }\end{array}$} \\
\hline & $\overline{\mathbf{x}}$ & $\mathrm{S}$ & $\overline{\mathbf{x}}$ & s & $\overline{\mathbf{x}}$ & S & NS & .05 & .01 & .001 \\
\hline $\begin{array}{l}\text { Kuiva-aine }, \ldots . . . . . \\
\text { Dry matter, } \%\end{array}$ & 31.4 & 7.2 & 37.5 & 17.2 & 30.8 & 13.8 & $\mathrm{ABC}$ & & & \\
\hline $\begin{array}{l}\text { R. proteiini ........... } \\
\text { Crude protein }\end{array}$ & 19.4 & 2.8 & 19.5 & 1.6 & 18.2 & 3.4 & $\mathrm{ABC}$ & & & \\
\hline $\begin{array}{l}\text { R. kuitu .............. } \\
\text { Crude fibre }\end{array}$ & 26.4 & 3.6 & 27.0 & 2.8 & 25.6 & 3.4 & $\mathrm{ABC}$ & & & \\
\hline $\begin{array}{l}\text { Tuhka } \\
\text { Ash }\end{array}$ & 9.5 & 1.8 & 9.6 & 0.9 & 9.3 & 2.4 & $\mathrm{ABC}$ & & & \\
\hline $\begin{array}{l}\text { Sokerit ................... } \\
\text { Sugars }\end{array}$ & 2.2 & 2.5 & 4.0 & 2.9 & 4.7 & 3.6 & B & & $\mathrm{AC}$ & \\
\hline $\begin{array}{l}\text { Org. hapot ............. } \\
\text { Organic acids }\end{array}$ & 13.7 & 2.4 & 10.9 & 3.2 & 10.6 & 3.2 & B & & & $\mathrm{AC}$ \\
\hline 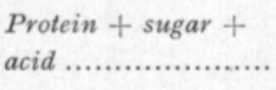 & 35.3 & 4.4 & 34.4 & 2.4 & 33.5 & 4.1 & $\mathrm{ABC}$ & & & \\
\hline $\begin{array}{l}\text { In vitro digestib, of } \\
O M, \% \ldots \ldots . . . . . . .\end{array}$ & 72.6 & 3.0 & 65.8 & 2.6 & 67.7 & 3.3 & & B & & $\mathrm{AC}$ \\
\hline $\begin{array}{l}\text { In vitro digestib, of } \\
D M, \% \ldots \ldots \ldots . . .\end{array}$ & 73.1 & 3.1 & 66.6 & 2.8 & 67.5 & 4.0 & B & & & AC \\
\hline $\begin{array}{l}\text { Mcal. ME/kg ka } \\
D M\end{array}$ & 2.57 & 0.13 & 2.37 & 0.10 & 2.40 & 0.16 & B & & & AC \\
\hline 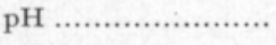 & 4.2 & 0.5 & 4.3 & 0.4 & 4.1 & 0.5 & $\mathrm{ABC}$ & & & \\
\hline $\mathrm{NH}_{3}-\mathrm{N}, \%$ of total $\mathrm{N}$ & 6.4 & 7.4 & 3.7 & 3.0 & 3.7 & 1.4 & $\mathrm{ABC}$ & & & \\
\hline
\end{tabular}

1) $\mathrm{A}=1-2, \mathrm{~B}=2-3, \mathrm{C}=1-3$.

\section{Koostumusmuutokset säilöntäaikana}

Säilörehu on raaka-ainettaan huonompaa rehua, koska käymisprosessit ja puristemehussa huuhtoutuvat aineet alentavat sen ravintoarvoa. Tutkimuksessa pyrittiin selvittelemään, kuinka paljon ruohon koostumus ja rehuarvo muuttuu ja mitkä tekijät vaikuttavat muutoksiin.

Es i k u i v a t u/n i i t o t u or e. Esikuivatuiksi laskettiin kaikki näytteet, joita vähänkin oli esikuivattu, ja ryhmässä olivat mukana myös kaikki kuivumisen eri vaiheissa sadetta saan€et. Niittotuoreryhmä taas käsitti ne näytteet, jotka oli niitetty kelasilppurilla ja ajettu heti siiloon. Esikuivatuissa ruohon ka-pitoisuus oli $14-76 \%$, niittotuoreissa $13-25 \%$ (yksi näyte $34 \%$ ).

Ero esikuivatun hyväksi oli ilmeinen (taulukko 5): ruohon sulavuus ja sokerisekä tuhkapitoisuus aleni ja kuitupitoisuus nousi merkitsevästi vähemmän kuin niittotuoreissa $(\mathrm{P}<0.01)$. Ero joutui selvästikin alemmasta vesipitoisuudesta.

Kuiva-ainetappion suuruuden vaikutus. Säilörehut jaettiin tässä tapauksessa viideksi ryhmäksi kuiva-ainetappion suuruuden 
Taulukko 5. Koostumusmuutos säilönnän aikana ryhmissä esikuivatut (1) ja niittotuoreet (2), \%-yks. ka:sta.

Table 5. Chemical changes during ensilage in groups of wilted (1) and fresh (2) material, \% units of DM.

\begin{tabular}{|c|c|c|c|c|c|}
\hline & \multicolumn{2}{|c|}{$\begin{array}{c}1 \\
(n=65)\end{array}$} & \multicolumn{2}{|c|}{$(n=22)$} & \multirow{2}{*}{$\begin{array}{c}\text { Merkitsevyys } \\
\text { Significance } \\
\text { (T-value) }\end{array}$} \\
\hline & $\bar{x}$ & $\mathrm{~S}$ & $\overline{\mathbf{x}}$ & $\mathrm{S}$ & \\
\hline Kuiva-aine - Dry matter ........... & -0.1 & 5.0 & +5.0 & 2.9 & .001 \\
\hline R. proteiini - Crude protein ....... & -0.3 & 1.5 & +0.6 & 2.2 & NS \\
\hline R. kuitu - Crude fibre ............ & +2.1 & 2.3 & +3.6 & 1.7 & .01 \\
\hline Tuhka - Ash ........................ & -0.1 & 1.1 & -1.0 & 1.7 & .01 \\
\hline Sokerit - Sugars .................... & -5.9 & 3.6 & -8.6 & 3.3 & .01 \\
\hline Org. hapot - Organic acids ...... & +6.9 & 3.3 & +6.7 & 2.5 & NS \\
\hline In vitro digestib. of $O M \quad \ldots . . . . .$. & -2.3 & 2.6 & -4.3 & 2.8 & .01 \\
\hline Mcal. ME/kg ka-DM ........... & -0.09 & 0.10 & -0.13 & 0.10 & NS \\
\hline pH & 4.3 & 0.5 & 3.9 & 0.4 & .01 \\
\hline $\mathrm{NH}_{3}-\mathrm{N}, \%$ of total $\mathrm{N} \ldots \ldots \ldots \ldots$ & 5.4 & 6.4 & 4.0 & 1.2 & NS \\
\hline Ruohon ka-\%, DM \% of grass & 35.2 & 14.8 & 19.5 & 6.4 & .001 \\
\hline
\end{tabular}

mukaan, ääriryhmät olivat yli $25 \%$ ja alle $5 \%$. Taulukosta 6 käy ilmi, että suuri säilöntätappio muutti ruohon koostumusta hyvin huomattavasti huonompaan suuntaan. Selvimpänä muutos näkyy kuitupitoisuuden nousuna ja su'avuuden alenemisena. Muutosten erot saattavat jo peräkkäisten ryhmien välillä olla erittäin merkitseviä. Proteiinipitoisuus muuttuu hyvin vähän, mikä onkin ymmärrettävää, koska proteiinia häviää suunnilleen samassa suhteessa kuin kuiva-ainetta (taulukko 9). Taulukosta näkyy vielä, että ruohon korkea vesipitoisuus on eräs tappioita ja koostumuksen sekä laadun huononemista aiheuttava tekijä.

T i e t y t hait tat e kijät. Omiksi ryhmikseen kerättiin nyt ne koesäkit, joilla voitiin osoittaa tietty säilöntätulosta huonontava tekijä. Yhden ryhmän muodostivat ne ruohot, jotka oli ajettu siiloon sateella, toisen ne, joihin siilossa oli päältä valunut huomattavan runsaasti puristemehua (säkin yläpuolelle oli ajettu märkää ruohoa tai naatteja) ja kolmannen ne esikuivatut, jotka oli säilötty ilman säilöntäainetta. Loput sijoitettiin ryhmään 4 .

Taulukosta 7 käy ilmi, että päältä valuva runsas puristemehu saa aikaan suuremman rehuarvon alenemisen kuin ruohoon korjuuvaiheessa tullut sade. Sulavuuden ja kuitu- sekä tuhkapitoisuuden muutokset ovat ryhmiin 3 ja 4 verrattuna erittäin merkitseviä. Sateella korjatussa ruohossa todetaan samat negatiiviset muutokset, mutta vähän lievempinä. Ilman happoa säilötyissä on tapahtunut voimakasta käymistä, mutta silti rehuarvo on laskenut vain hyvin vähän. Korkea $\mathrm{NH}_{3}-\mathrm{N}$ ja $\mathrm{pH}$ viittaa siihen, etteivät kaikki tämän ryhmän rehuerät olleet laadullisesti moitteettomia. Huomattava osa tämän ryhmän ruohosta sisälsi vettä yli $70 \%$ ja se merkitsee kevätruohoa ilman happoa säilöttäessä laadun huononemisen riskiä.

Si i lo n o s a. Siilon eri osan vaikutusta tutkittaessa näytesäkit jaettiin täyttövaiheen sijainnin mukaan kolmeksi ryhmäksi: alimmat $3 \mathrm{~m}=$ alaosa, seuraavat $3 \mathrm{~m}=$ keskiosa, ylimmät $3 \mathrm{~m}=$ yläosa. Osien välillä todettiin vain yksi selvä ero: happojen pitoisuus nousi ja sokeripitoisuus laski siilon pohjaa 


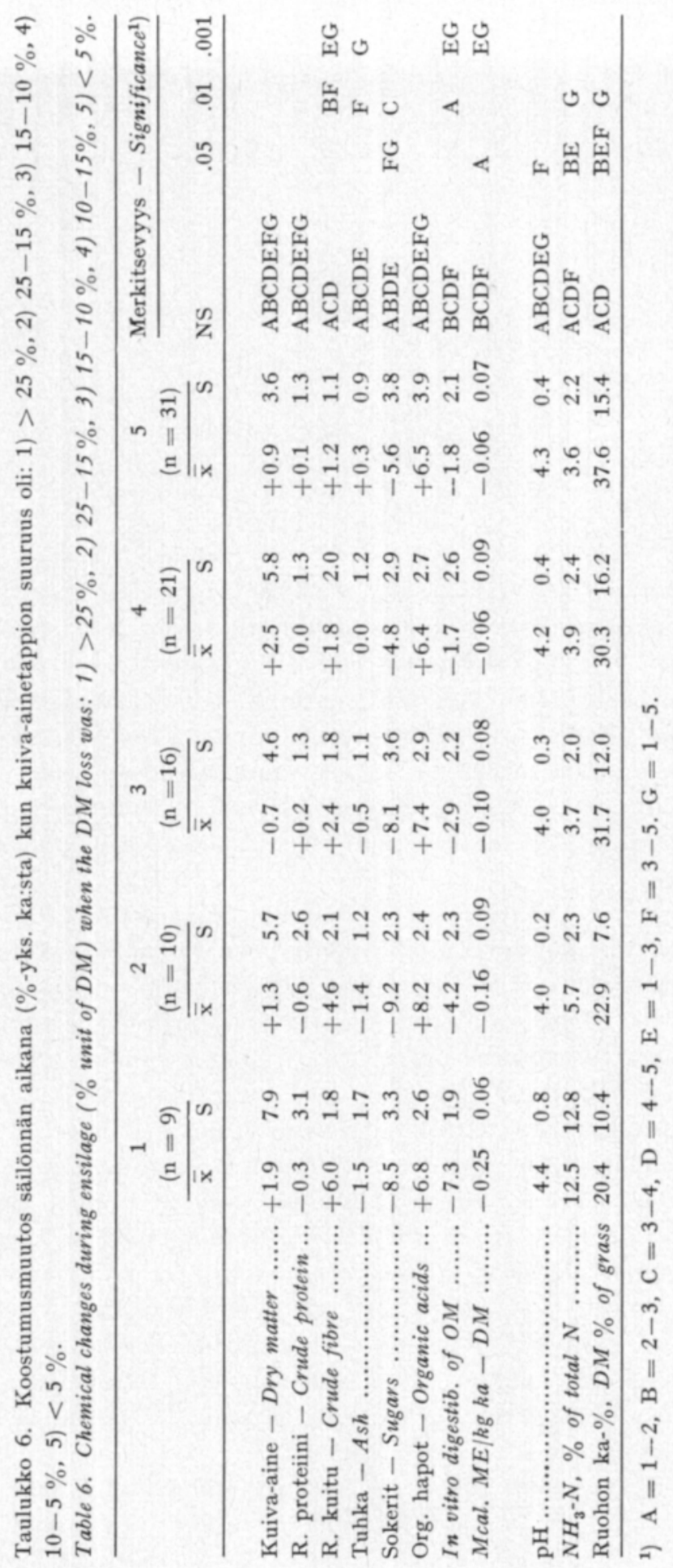




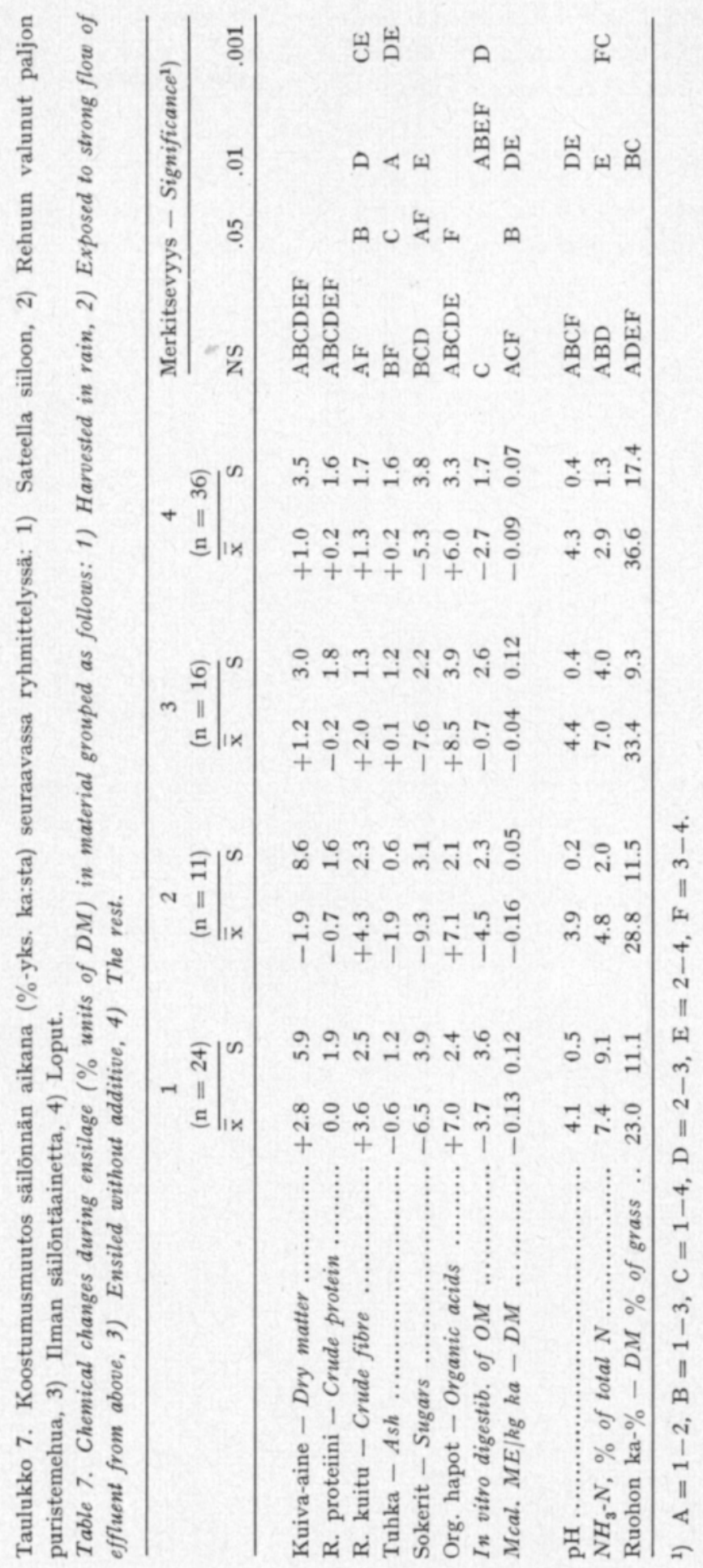


kohti, ero ala- ja keskiosan välillä oli merkitsevä $(\mathrm{P}<0.001)$. Selitys lienee kuitenkin siinä, että alimmassa kolmanneksessa peräti $73 \%$ säkeistä oli 1 . korjuukerran rehua, missä tapahtui muita voimakkaampi käyminen (taulukko 4).

Vuonna 1972 verrattiin rinnakkaissäkeillä siilon keskiosaa ja laitaa, mutta mitään johdonmukaista eroa niiden välillä ei todettu.

\section{Säilöntätappiot}

Taulukosta 8 nähdään koesäkkien prosenttinen jakautuminen eri tappioryhmiin. Suuria tappioita on tapahtunut niittotuoreissa huomattavasti enem-

Taulukko 8. Koesäkkien jakautuminen eri ka-tappioryhmiin.

Table 8. Distribution of experimental sacks by DM losses.

\begin{tabular}{|c|c|c|c|c|c|c|c|c|c|}
\hline Ka-tappio & Esikuivatut & Niittotuoreet & Korjuu & kerrat - & Cuttings & & Vuodet & - Years & \\
\hline DM loss & $\begin{array}{c}\text { Wilted } \\
(\mathrm{n}=65) \\
\%\end{array}$ & $\begin{array}{c}\text { Fresh } \\
(\mathrm{n}=22) \\
\%\end{array}$ & $\begin{array}{c}1 \\
(\mathrm{n}=42) \\
\%\end{array}$ & $\begin{array}{c}2 \\
(\mathrm{n}=20) \\
\%\end{array}$ & $\begin{array}{c}3 \\
(n=25) \\
\%\end{array}$ & $\begin{array}{c}1970 \\
(\mathrm{n}=23) \\
\%\end{array}$ & $\begin{array}{c}1971 \\
(\mathrm{n}=16) \\
\%\end{array}$ & $\begin{array}{c}1972 \\
(\mathrm{n}=27) \\
\%\end{array}$ & $\begin{array}{c}1973 \\
(\mathrm{n}=21) \\
\%\end{array}$ \\
\hline$>25$ & 6.2 & 22.7 & 9.5 & 0.0 & 20.0 & 13.0 & 12.5 & 14.8 & 0.0 \\
\hline $25-15$ & 7.7 & 22.7 & 16.7 & 0.0 & 12.0 & 8.7 & 12.5 & 14.8 & 9.5 \\
\hline $15-10$ & 16.9 & 22.7 & 16.7 & 20.0 & 20.0 & 21.7 & 18.8 & 11.1 & 23.8 \\
\hline $10-5$ & 27.7 & 13.6 & 16.7 & 45.0 & 20.0 & 30.4 & 12.5 & 22.2 & 28.6 \\
\hline$<5$ & 41.5 & 18.3 & 40.4 & 35.0 & 28.0 & 26.2 & 43.7 & 37.1 & 38.1 \\
\hline
\end{tabular}

män kuin esikuivatuissa, 2. korjuukerran rehussa muita vähemmän ja sadekesän 1972 rehussa muita enemmän. Jo tulosten pintapuolinen tarkastelu osoittaa, että pahin säilöntätappioita aiheuttava tekijä on korkea vesipitoisuus. Raaka-aineen vesipitoisuus selvitettiin tekovaiheessa, mutta puristemehun määrää voitiin vain arvailla sen mukaan, kuinka märkää rehua oli pantu näytekerroksen päälle. Kaksi seuraavaa ryhmittelyä selvittelee vesipitoisuudtn vaikutusta tappioihin.

Esikuivatut/niit ot u oreet. Ruohon vesipitoisuuden vaikutus tulee tässä ryhmittelyssä (taulukko 9) esille varsin karkeasti, koska esikui-

Taulukko 9. Säilöntätappiot (\%) ryhmissä esikuivatut (1) ja niittotuoreet (2).

Table 9. Preservation losses (\%) in groups of wilted (1) and fresh (2) material.

\begin{tabular}{|c|c|c|c|c|c|}
\hline & \multicolumn{2}{|c|}{$\begin{array}{c}1 \\
(n=65)\end{array}$} & \multicolumn{2}{|c|}{$\begin{array}{c}2 \\
(n=22)\end{array}$} & \multirow{2}{*}{$\begin{array}{l}\text { Merkitsevyys } \\
\text { Significance } \\
\text { (T-value) }\end{array}$} \\
\hline & $\overline{\mathbf{x}}$ & $\mathrm{S}$ & $\overline{\bar{x}}$ & $\mathrm{~s}$ & \\
\hline Tuorepaino - Fresh weight .... & 13 & 14 & 33 & 15 & .001 \\
\hline Kuiva-aine - Dry matter ........ & 8.5 & 8.3 & 15.0 & 9.5 & .01 \\
\hline R. proteiini - Crude protein ... & 9.7 & 10.5 & 13.0 & 12.0 & NS \\
\hline Tuhka - Ash ................... & 13.3 & 12.1 & 25.4 & 13.3 & .001 \\
\hline Org. hapot - Organic acids ... & -120 & 63 & -106 & 63 & NS \\
\hline In vitro digestible $O M . . . \ldots \ldots . .$. & 11.3 & 9.8 & 20.0 & 11.4 & .002 \\
\hline ME - Metabolizable energy .... & 11.1 & 10.2 & 18.8 & 11.0 & .01 \\
\hline Ruohon ka- $\%-D M \%$ of grass & 35.2 & 14.8 & 19.5 & 6.4 & .001 \\
\hline
\end{tabular}




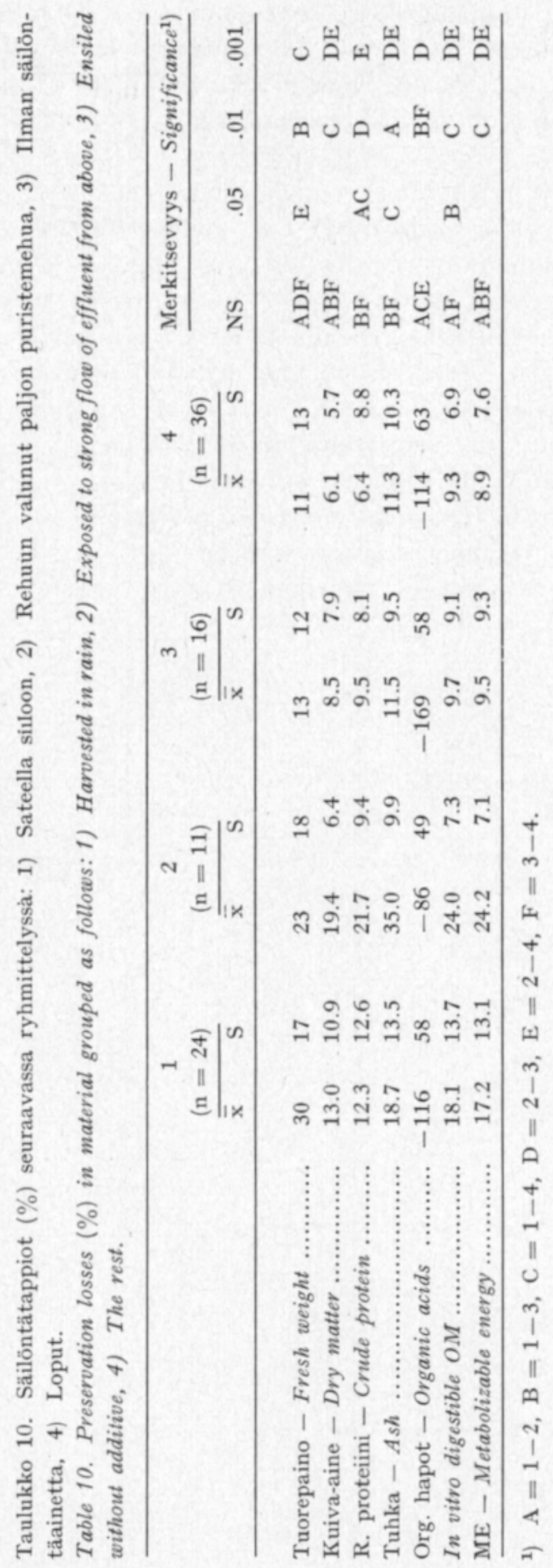


vattujen ryhmässä on monta sateen kastelemaa näytettä. Silti ME- ja tuhkatappiot ovat esikuivatuissa merkitsevästi pienemmät kuin niittotuoreissa $(\mathrm{P}<0.01)$, proteiinitappioiden ero sen sijaan ei ole tilastollisesti merkitsevä. Käymishappoja rehussa muodostuu niin runsaasti, että happojen määrä lisääntyy suuristakin ka-tappioista huolimatta. Happotappioita (lisäystä) laskettaessa on otettu huomioon ruohossa olevat orgaaniset hapot, joita on noin $5 \%$ ka:sta.

Tietyt haittatekijät. Ryhmitys on sama (taulukko 10) kuin edellä taulukossa 7. Suurimmat tappiot aiheutti päältä valunut runsas puristemehu, se oli pahempi tappiotekijä kuin ruohon ajaminen sademärkänä siiloon. Puristemehu huuhtoi rehusta erikoisesti tuhkaa ja proteinia. Tappioerot kahden märän ryhmän (n:ot 1 ja 2) ja erotuksena saadun ryhmän n:o 4 välillä ovat monien aineiden kohdalla erittäin merkitseviä. Hapon poisjättäminen (n:o 3) aiheutti normaalia voimakkaamman käymisen, mutta silti tappiot eivät olleet ryhmään n:o 4 verrattuna merkitseviä. Sulavan aineen tappiot olivat kuiva-ainetappioihin verrattuna tässä ryhmässä pienet viitaten siihen, että runsas käyminen parantaa rehun sulavuutta.

$\mathrm{K}$ or j u u k r t a. Korjuukertojen vertailu (taulukko 11) osoittaa jälleen, että ruohon vesipitoisuus ja tappion suuruus kytkeytyvät kiinteästi yhteen. Kuivimpana siiloon ajetussa 2 . korjuun rehussa tappiot ovat pienimmät, 3 .

Taulukko 11. Säilöntätappiot (\%) 1., 2. ja 3. korjuukertana.

Table 11. Preservation losses (\%) of 1st, 2 nd and 3 rd cuttings.

\begin{tabular}{|c|c|c|c|c|c|c|}
\hline 1 & 2 & 3 & Mer & ievy? & Sign & ance $e^{1}$ \\
\hline $\mathrm{n}=42)$ & $(\mathrm{n}=20)$ & $(\mathrm{n}=25)$ & & & & \\
\hline$\overline{\mathrm{s}}$ & $\overline{\mathbf{x}}$ & $\overline{\overline{\mathrm{x}}}$ & NS & .05 & .01 & .001 \\
\hline
\end{tabular}

\begin{tabular}{|c|c|c|c|c|c|c|c|c|c|}
\hline $\begin{array}{l}\text { Tuorepaino ............ } \\
\text { Fresh weight }\end{array}$ & 14 & 15 & 16 & 15 & 27 & 18 & A & B & C \\
\hline $\begin{array}{l}\text { Kuiva aine } \\
\text { Dry matter }\end{array}$ & 10.6 & 10.0 & 6.4 & 3.4 & 12.3 & 9.6 & $\mathrm{AC}$ & B & \\
\hline $\begin{array}{l}\text { R. proteiini ........... } \\
\text { Crude protein }\end{array}$ & 13.2 & 13.5 & 7.0 & 5.6 & 8.8 & 8.3 & $\mathrm{ABC}$ & & \\
\hline $\begin{array}{l}\text { Tuhka } \ldots \ldots \ldots \ldots \ldots \ldots . . . \\
\text { Ash }\end{array}$ & 17.7 & 14.8 & 8.3 & 4.8 & 20.5 & 13.3 & $\mathrm{C}$ & & A \\
\hline $\begin{array}{l}\text { Org. hapot ............. } \\
\text { Organic acids }\end{array}$ & 138 & 60 & -114 & 62 & -98 & 64 & $A B$ & $\mathrm{C}$ & \\
\hline In vitro digestible $O M$ & 13.3 & 11.6 & 9.5 & 5.7 & 16.9 & 11.7 & $\mathrm{AC}$ & B & \\
\hline $\begin{array}{l}\text { ME .......................... } \\
\text { Metabolizable energy }\end{array}$ & 13.2 & 12.2 & 9.5 & 6.2 & 15.7 & 10.9 & $\mathrm{AC}$ & B & \\
\hline $\begin{array}{l}\text { Ruohon ka- } \% \text {....... } \\
D M \text { of grass }\end{array}$ & 31.9 & 10.4 & 37.3 & 20.8 & 27.4 & 16.2 & & & \\
\hline
\end{tabular}

1) $\mathrm{A}=1-2, \mathrm{~B}=2-3, \mathrm{C}=1-3$. 
korjuun rehussa suurimmat. Orgaanisten happojen lisäys on 1. korjuun rehussa muita suurempi voimakkaamman käymisen vuoksi. Raakaproteiinitappioihin vaikuttaa myös rehun raakaproteiinipitoisuus, kuten 1. ja 3. korjuun ruohoa ja tappioita vertailemalla voidaan todeta. Ylipäänsä erot korjuukertojen välillä ovat tilastollisesti katsoen vähäiset ja niiden selitykseksi riittää erilainen vesipitoisuus.

Vuodet $1970-1973$. Vuosien paremmuusjärjestys tappioiden perusteella oli: 1973, 1971, 1972 ja 1970, proteiinitappioissa sadekesä 1972 oli huonoin. Tappiot myötäilevät jälleen ruohon vesipitoisuutta, poikkeuksena oli vain vuosi 1972, jolloin esikuivatun ja märän ruohon pano siiloon vuoroıellen aiheutti 1. korjuun rehussa suuret tappiot. Ero parhaan vuoden (1973) ja huonoimman (1970) välillä oli energiatappioissa hyvin merkitsevä $(\mathrm{P}<0.01)$, proteiinitappioissa vähän tätä alempi $(\mathrm{P}<0.02)$ ja tuorepainotappioissa erittäin merkitsevä $(\mathrm{P}<0.001)$. Samansuuruinen ero oli myös ruohon ka-pitoisuudessa (1970: $21 \pm 6.8 \%$ ka, 1973: $33.7 \pm 10.6 \%$ ka, $\mathrm{P}<0.01)$.

S i i l o n o s a t. Ainoa selvä ero oli erittäin merkitsevästi suurempi happolisäys $(\mathrm{P}<0.001)$ alimmassa kolmanneksessa, mutta kuten jo on mainittu syynä siihen - ainakin huomattavana osasyynä - oli 1. korjuun ruohon suuri osuus (73\%) alimman kolmanneksen näytteistä. Muiden aineryhmien tappioissa ei ollut merkitseviä eroja, mutta sitä ei liioin ollut siilon eri osiin pannun ruohon keskimääräisessä ka-pitoisuudessa.

\section{Korrelaatiot}

Tuloksista laskettiin eri pitoisuuksien, koostumusmuutosten ja tappioiden välisiä korrelaatiokertoimia.

Ruohossa ilmeni kiinteitä korrelaatioita monien aineryhmien välillä (taulukko 12). Säilönnän aikana tapahtui muutoksia erikoisesti orgaanisten happojen ja sokerien suhteessa rehun muihin aineosiin. Sulavuuden riippuvuus kuitu- ja proteiinipitoisuudesta väheni hieman, mutta oli vieläkin erittäin merkitsevä (taulukko 13).

Korrelaatiolaskuista kävi myös ilmi, että säilönnän aikana tapahtuvat kuitu- ja tuhkapitoisuuden sekä sulavuuden muutokset ovat keskenään kiinteässä vuorosuhteessa $(\mathrm{P}<0.001)$. Proteiini- ja happopitoisuuden muutokset taas ovat toisistaan ja enimmäkseen myös muiden aineosien muutoksista riippumattomia. Niinikään kävi ilmi, että eri aineryhmien tappioiden välillä vallitsee happoja lukuunottamatta erittäin kiinteä vuorosuhde $(\mathrm{P}<0.001)$. Erikoisen selvästi myötäili kuiva-ainetappioita sekä sulavan orgaanisen aineen että muuntokelpoisen energian häviö $(r=.97)$.

Kokeissa pantiin useaan kertaan merkille, että märkäkään ruoho ei johtanut suuriin tappioihin, kun se tuli siilon pohjalle. Taulukosta 14 voidaan todeta sama seikka ruohon kuiva-ainepitoisuuden ja tappioiden välisenä korrelaationa: alaosassa korrelaatioita ei ole, paitsi luonnollisesti tuorepainon kohdalla, yläosassa vallitsee kiinteä korrelaatio. Selitys lienee siinä, että alaosassa rehupatsaan paino puristaa liikakosteuden - nimenomaan sadeveden - pois niin nopeasti, että käymisprosessit eivät ehdi lisätä ravintoaineiden liukoisuutta. Yläosassa paino on pienempi ja puristuminen tapahtuu hitaammin. Osalla näytteitä alla oleva muovikalvo vielä hidasti mehun puristumista. 
Taulukko 12. Ruohon eri pitoisuuksien ( $\%$ ka:sta) in vitro -sulavuuden ja Mcal--arvon väliset korrelaatiokertoimet $(\mathrm{n}=45)$.

Table 12. Correlation coefficients between the various components ( $\%$ of DM), in vitro digestibility and Mcal. value of grass $(n=45)$.

$\begin{array}{lllllllll}1 & 2 & 3 & 4 & 5 & 6 & 7 & 8 & 9\end{array}$

1. R.proteiini - Crude protein 1.00

2. R.kuitu - Crude fibre ...... $-.40^{2} \quad 1.00$

3. Tuhka $-A s h \quad \ldots . . . . . . . . . .6 \quad .11 \quad-.35^{1} \quad 1.00$

4. Sokerit - Sugars $\ldots \ldots \ldots \ldots . . .21-.42^{2}-.14 \quad 1.00$

5. Org. hapot - Organic acids $\quad .36^{1}-.42^{2} \quad .05 \quad-.05 \quad 1.00$

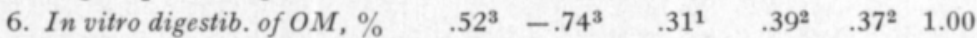

7. $, D M, \% \quad .62^{3}-.67^{3} \quad .09 \quad .33^{1} \quad .41^{2} \quad .94^{3} \quad 1.00$

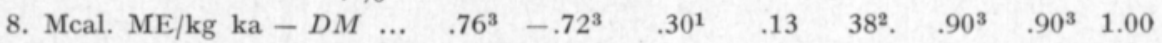

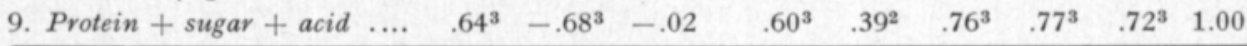

$1=\mathrm{P}<0.05,{ }^{2}=\mathrm{P}<0.01,{ }^{3}=\mathrm{P}<0.001$.

Taulukko 13. Säilörehun eri pitoisuuksien ( $\%$ ka:sta), in vitro -sulavuuden ja Mcal.-arvon väliset korrelaatiokertoimet $(\mathrm{n}=87)$.

Table 13. Correlation coefficients between the various components ( $\%$ of DM), in vitro digestibility and Mcal, value of silages $(n=87)$.

\begin{tabular}{lllllllllll}
\hline 1 & 2 & 3 & 4 & 5 & 6 & 7 & 8 & 9 \\
\hline
\end{tabular}

1. R.proteiini - Curde protein 1.00

2. R. kuitu - Crude fibre ...... $-.51^{3} \quad 1.00$

3. Tuhka $-A s h \quad \ldots . . . . . . . . . . .21^{1} \quad-.36^{3} \quad 1.00$

4. Sokerit - Sugars $\ldots \ldots \ldots \ldots . . .26^{1}-.28^{2} \quad .04 \quad 1.00$

5. Org. hapot - Organic acids $\quad .37^{3} \quad-.17 \quad .02 \quad-.71^{3} \quad 1.00$

6. In vitro digestib. of $O M, \begin{array}{lllllll}\% & .46^{3} & -.61^{3} & .21^{1} & -.11 & .45^{3} & 1.00\end{array}$

7. $, D M, \% \quad .46^{3}-.58^{3} \quad .06 \quad-.09 \quad .48^{3} \quad .96^{3} \quad 1.00$

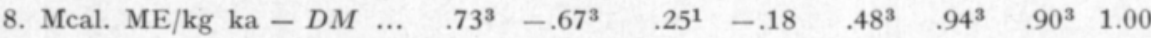

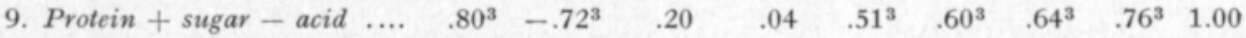

$1=\mathrm{P}<0,05,{ }^{2}=\mathrm{P}<0,01,{ }^{3}=\mathrm{P}<0.001$.

Taulukko 14. Tappion (\%) riippuvuus ruohon ka-prosentista $9 \mathrm{~m}$ korkeiden siilojen alimmassa (1), keskimmäisessä (2) ja ylimmässä (3) kolmanneksessa.

Table 14. Dependence of losses (\%) on the DM \% of grass in the lower (1), middle (2) and upper (3) third of the 9-m-high silos.

\begin{tabular}{|c|c|c|c|c|}
\hline & $\begin{array}{c}1 \\
(n=37)\end{array}$ & $\begin{array}{c}2 \\
(n=12)\end{array}$ & $\begin{array}{c}3 \\
(n=38)\end{array}$ & $\begin{array}{c}\bar{x} \\
(n=87)\end{array}$ \\
\hline Tuorepaino - Fresh weight ............... & $-.80^{3}$ & $-.65^{1}$ & $-.74^{3}$ & $-.72^{3}$ \\
\hline Kuiva-aine - Dry matter ................... & -.18 & -.45 & $-.51^{3}$ & $-.37^{3}$ \\
\hline R. proteiini - Crude protein ............... & -.16 & $-.58^{1}$ & $-.41^{2}$ & $-.35^{3}$ \\
\hline 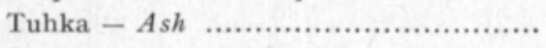 & -.14 & -.43 & $-.53^{3}$ & $-.38^{3}$ \\
\hline 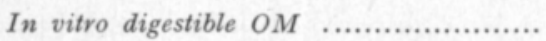 & -.19 & $-.55^{1}$ & $-.53^{3}$ & $-.42^{3}$ \\
\hline Mcal. ME ...................................... & -.17 & $-.54^{1}$ & $-.52^{3}$ & $-.41^{3}$ \\
\hline Ruohon ka- $\%-D M \%$ of grass ....... & $28.4 \pm 11.0$ & $34.9 \pm 21.7$ & $32.9 \pm 15.4$ & $31.3 \pm 14.8$ \\
\hline
\end{tabular}

$1=\mathrm{P}<0.05,{ }^{2}=\mathrm{P}<0.01,{ }^{3}=\mathrm{P}<0.001$. 


\section{Tulosten tarkastelua}

Tutkimuksessa pyrittiin vertailemaan myös energia-arvoa. Sen laskemiseen kokeiltiin TERRYn ym. (1974) ruohoille ja AERTsin ym. (1974) ruohoille ja säilörehuille laatimia kaavoja. Edellinen kaava, jossa D-arvon ja raakaproteiinin perusteella lasketaan ME-arvo, antoi luotettavan tuntuisia tuloksia. Kun laskettu ME-arvo muunnettiin ry-arvoksi kertoimella 0.31 (NJF:n rehutaulukoissa nurmisäilörehujen ry-arvo on $=0.30-0.32 \times$ Mcal.-arvo). saatiin ruohojen keskimääräiseksi täyttävyysluvuksi 1.25 ja vastaavien säilörehujen 1.30. AERTsin ym. (1974) kaavoilla virallisen rehuanalyysin tuloksista laskettu ty-arvo ei vaikuttanut uskottavalta, mm. säilörehujen ry-arvoksi tuli korkeampi luku kuin vastaavien ruohojen.

Korkea vesipitoisuus osoittautui pahimmaksi haittatekijäksi. Niittotuoreissa oli sen vuoksi sulavien aineiden pitoisuuden lasku ja ME-tappio merkitsevästi suurempi kuin esikuivatuissa $(\mathrm{P}<0.01)$. Sateella siiloon ajetut ja vielä enemmän märän rehun alle joutuneet näytteet nostivat keskimääräisiä tappiolukuja. Pahimmiksi virheiksi säilörehun teossa todettiin seuraavat: 1) Ruohoa kuivattiin pari vuorokautta, sitten tuli sade ja ruoho ajettiin märkänä (17 \% ka) entisen rehun päälle. Tuloksena oli kokeen suurimmat tappiot ja heikkolaatuisin rehu. Vahinko kohdistui myös alla olevaan rehuun. 2) Sadesään ruohoa $(13-17 \% \mathrm{ka})$ ajettiin niittotuoreena siiloon entisen päälle. Tappio kohdistui jälleen myös alla olevaan rehuun. Laadullisesti tämä rehu ei ollut yhtä heikkoa kuin kohdan 1 esikuivattu. 3) Esikuivatun kevätrehun päälle pantiin syksyllä mehevää odelmaa $(13-17 \%$ ka). 4) Syksyn niittotuoreen rehun päälle pantiin lokakuussa sokerijuurikkaan naatteja $(11-14 \%$ ka). Kahdessa viimeksimainitussa tapauksessa välissä oli saumaamaton muovikalvo, mutta puristemehu aiheutti silti tappioita usean metrin matkalla. Näyttää siltä, että muovikalvosta on tosin hyötyä rehun pinnan suojana, mutta ei kerrosten välissä: se ei estä puristemehun valumista, mutta hidastaa sitä ja lisää siten käymistä muovin päälle tulevassa kerroksessa. Myös Etrala ym. (1972) ovat todenneet, ettei muovikalvon käyttö eri kerrosten välillä johtanut toivottuun tulokseen.

Esikuivatuksen edut tunnetaan yleisesti: koska puristemehua ei muodostu ja käyminen vähenee, vähenevät säilöntätappiot. Gross ja Averdunkin (1968) mukaan kuiva-ainepitoisuuden nousu $1 \%$-yksiköllä alentaa ka-tappioita $0.54 \%$-yksiköllä. Fermentaation hidastuessa sokeria säästyy ja maitohapon osuus hapoista nousee, minkä ansiosta rehun energia-arvo ja laatu säilyy hyvänä (Maskova ja Havelik 1969, Gross ja Riebe 1974). $30 \%$ :n ka-pitoisuus on tietynlainen raja: sen yläpuolella ei puristu mehua (Gross ja RIEBE 1974) ja myös virhekäymismahdollisuus vähenee (WEISE ja HorNIG 1975). Eri tutkijain mielipiteet taloudellisesti edullisimmasta ka-pitoisuudesta liikkuvat $30 \%$ :n ja 45-55 \%:n välillä (MASKova ja HAVELIK 1969); laskuissa on silloin huomioitu esikuivatuksen aiheuttamat peltotappiot, mitkä ovat 1-4\% ja sateen sattuessa suuremmatkin (McDonald ym. 1968, Gross ja RiEbe 1974). Myös niittotuoreessa säilönnässä on todettu korkean ka-pitoisuuden edut (Ettala ym. 1972, Skovborg ja Andersen 1973). Vuyst ym. (1975) korostavat, että säilöttävän ruohon ka-pitoisuus pitäisi olla vähintäin $20 \%$. 
Märän ruohon pano entisen rehun päälle osoittautui erittäin tuhoisaksi, mikä onkin ymmärrettävää, koska puristemehu sekä huuhtoo mukaansa ravintoaineita, että saa aikaan kiihtyvän käymisen. Kirjallisuudessa tätä puolta on käsitelty vähän. GRoss ja RIEBE (1974) esittävät, että ruoho pitäisi säilöä eri korjuukerroilla eri siiloihin tai jälkitäytössä kuivata vähintäin $30 \%$ :n kapitoisuuteen.

Koostumus- ja rehuarvonmuutokset riippuivat ka-tappioiden suuruudesta. Noin $30 \%$ :lla koesäkeistä ME-arvo laski enintään $1.5 \% \quad(0-0.05$ Mcal./kg ka), mutta sateella korjatuissa ja runsaan puristemehun huuhtomissa näytteissä lasku oli keskimäärin 5-6\%, ääritapauksissa $10-12 \%$. Keskiarvo oli $3.5 \%$ (0.09 Mcal $/ \mathrm{kg} \mathrm{ka})$ ja suunnilleen sama $(3.7 \%)$ oli orgaanisen aineen in vitro -sulavuuden lasku. Energia-arvon alenemisen jääminen näinkin vähäiseksi johtuu siitä, että käymisprosessit ilmeisesti parantavat rehun sulavuutta. Tätä olettamusta tukee kaksi havaintoa: 1) voimakkaasti käyneiden lievästi esikuivattujen rehujen sulavuus laski erittäin vähän, 2) säilönnän aikana hävisi myös in vitro -sulamatonta ainetta (muuttui sulavaksi). Sama ilmiö todettiin aiemmin naattisäilörehukokeissa (SALo ym. 1974). Samaa osoittaa myös JACKsonin ja Andersonin (1968) havainto, että kaasutiiviissä siilossa säilörehun sulavuus oli raaka-aineen sulavuutta korkeampi.

Kuitupitoisuuden nousu korreloitui kiinteästi sulavuuden ja ME-arvon laskuun $(\mathrm{P}<0.001)$ ja kuvasi siten hyvin rehuarvon alenemista. Kuitupitoisuuden muutokset olivat samaa luokkaa, mitä muuallakin on todettu (PoutraInen ja Rinne 1971, Ettala ym. 1971, Henderson ym. 1971).

Happojen kokonaispitoisuus oli kuiva-aineesta laskettuna vähän alempi kuin Skovborgin ja Andersenin (1973) kokeissa, mutta huomattavasti korkeampi kuin EtTALAn ym $(1971,1975)$ toteama. Säilöntäaineen pois jättäminen lisää käymishappojen määrää, se todettiin näissä kokeissa ja on todettu muuallakin (HENDERSON ym. 1972). Toisaalta voidaan todeta monista taulukoista, että ruohon kuivaaminen noin $30 \%$ :n ka-tasolle ei vielä mainittavasti alentanut happopitoisuutta. Tämä pitää yhtä muualla tehtyjen havaintojen kanssa (skovborg ja Andersen 1973, Gross ja Riebe 1974).

Käyminen oli 1. korjuukerran rehussa merkitsevästi voimakkaampaa kuin 3. korjuun rehussa $(\mathrm{P}<0.001)$, vaikka ruohon ka-pitoisuus oli viimeksimainitussa alempi. Syynä oli selvästikin kesän korkea lämpötila. Syksyrehussa on muuallakin todettu kevätrehua vähäisempi käyminen (GRoss ja RıEBE 1974). Toisaalta voitiin todeta, ettei edes kylmä sää estänyt voimakasta käymistä, kun syyskuussa säilötyn nurmirehun päälle pantiin lokakuussa sokerijuurikkaan naatit.

Raakaproteiinipitoisuus pysyi säilönnän aikana muuttumattomana, osassa niittotuoreita rehuja se jopa nousi, koska proteiinitappiot olivat ka-tappioita pienemmät. Samanlaisia tuloksia on saatu muuallakin, proteiinipitoisuus on joko vähän noussut (Gordon ym. 1964, McDonald ym. 1968, Poutiainen ja Rinne 1971), tai vähän laskenut (EtTALA ym. 1972), mutta ero raaka-aineeseen ei koskaan ole ollut suuri.

Proteiinin laatu sen sijaan laski. Keskimäärin $\mathrm{NH}_{3}-\mathrm{N}$-pitoisuus oli matala, samaa luokkaa kuin Ettalan ym. $(1971,1975)$ toteama, mutta hajonta oli suuri. Vesipitoisuuden vaikutus tuli selvästi esille, kuten myös SkovBorGin ja 
ANDERSENin (1973) kokeissa. Laadultaan heikointa rehua (yli $25 \% \mathrm{NH}_{3}-\mathrm{N}$ ) saatiin esikuivatusta ruohosta, mikä sateen läpimäräksi kastelemana ajettiin siiloon. Vähäinen sade, mikä ei alentanut esikuivatun ka-pitoisuutta alle $30 \%$, ei saanut paljon vahinkoa aikaan. Säilöntäaineen kohdalla pantiin merkille, että jos halutaan välttää laadun huononeminen ja vähentää tappioita, pitää alle $30 \%$ ka sisältävään ruohoon - ainakin 1. korjuukertana ja siilon puolesta välistä ylöspäin - lisätä säilöntäainetta. Tätä kuivempaan ruohoon sitä tuskin tarvitaan. Samaan tulokseen on tullut Gross (1975). $\mathrm{pH}$ on laadun mitaksi huono, koska se esikuivatussa rehussa riippuu ka-pitoisuudesta. Vain hyvin heikkolaatuisissa rehuissa, missä suuri $\mathrm{NH}_{3}$-pitoisuus neutraloi happoja, näkyi huono laatu jo pH-luvusta.

Tutkimuksen taulukkotiedoista käy ilmi, että kun säilörehu tehtiin maatilan ohjelman mukaisesti (ruoho esikuivattiin kun sää salli, pouta- ja sadepäivän ruoho ajettiin samaan siiloon, syksyllä ajettiin märkää rehua entisen päälle ja muurahaishappoa käytettiin vain $0-0.30 \%$ ), tulosten hajonta oli paljon suurempi kuin koeoloissa tapahtuvassa säilönnässä (ETTALA ym. 1972, 1975). Tutkituista näytesäkeistä yli kolmanneksessa ka-tappio oli alle $5 \%$, monissa niistä nollan luokkaa. Toisaalta noin kymmenessä prosentissa tappio oli yli $25 \%$. Keskimääräiset tappiot olivat kuitenkin paljon pienemmät kuin mainituissa Ettalan ym. (1972) kokeissa, joissa ruoho säilöttiin niittotuoreena ja säilöntäainetta käytettiin $0.40-0.60 \%$. SkovBorgin ja AndERSENin (1973) tulokset muistuttavat tässä todettuja siinä, että ero poutaisen ja sateisen korjuukauden välillä oli hyvin suuri ja poutakaudella korjatun ruohon (23$33 \% \mathrm{ka})$ säilöntätappio oli heilläkin vain $1-2 \%$.

Selvittämättä jäi, mitä esikuivatulle ja sitten sateen läpikohtaisin kastelemalle ruoholle pitäisi tehdä. Ohjetta siihen ei löydetty liioin kirjallisuudesta. Entisen rehun päälle ajettuna se tuotti paljon vahinkoa. Turvallisinta olisi ajaa se tyhjän siilon pohjalle tai sen puuttuessa kuivata niin paljon, ettei ruohosta valu vettä. Kaikki siilojen pohjalle ajettu märkä ruoho - myös sateen kastelema lyhyen aikaa esikuivattu - onnistui hyvin, jos päälle saatiin vahva kerros niin kuivaa ruohoa, ettei siitä valunut mehua. Korkea rehupatsas puristaa liikakosteuden pois ennen kuin virhekäymisiä ehtii tapahtua ja myös tappiot jäävät vähäisiksi.

\section{Yhteenveto}

Nurmisäilörehun rehuarvon muutoksia ja säilöntätappioita käytännön oloissa tutkittiin Viikin koetilalla vuosina 1970-1973. Säilörehu tehtiin maatilan ohjelman mukaisesti neljään $9 \mathrm{~m}$ korkeaan ja $118-346 \mathrm{~m}^{3}$ :n vetoiseen betonisiiloon. 1. ja 2. korjuukerran ruoho oli laidun tai säilörehunurmilta, 3. korjuukerran ruoho niittonurmien odelmaa tai säilörehunurmen kolmatta satoa. Pääkasvilajeja olivat nurminata ja timotei. Ruohoa esikuivattiin aina kun sää sen salli, kuivausaika vaihteli 4 tunnista $4 \frac{1}{2}$ vuorokauteen. Esikuivatun ruohon ka-pitoisuus siiloon ajettaessa oli 14 (sateen kastelema) -76\%, niittotuoreen $13-25 \%$. Muurahaishappoa lisättiin esikuivattuun $0-0.15 \%$, sateen kastelemaan esikuivattuun ja niittotuoreeseen $0.30 \%$. Siilot täytettiin 
yksi kerrallaan, säästä riippumatta. 3. korjuukerran ruohosta suuri osa pantiin entisen rehun päälle, muovikalvo oli välissä.

Siiloihin pantiin lähes joka korjuupäivä juuttisäkkejä, joihin oli punnittu tietty määrä ruohoa. Säkkirehun perusteella laskettiin rehuarvon muutokset ja säilöntätappiot. Tulosten käsittelyssä oli 65 säkkiä esikuivattuja ja 22 säkkiä niittotuoreita. Näytteistä määritettiin eri aineosien lisäksi in vitro -sulavuus sekä laskettiin D-arvon ja raakaproteiinipitoisuuden perusteella ME-arvo.

Esikuivatussa rehuarvon lasku ja säilöntätappiot olivat merkitsevästi pienemmät kuin niittotuoreessa. Kun omiksi ryhmikseen koottiin 1) sateella siiloon ajatut, 2) ne joihin valui päältä runsaasti mehua, 3) ilman säilöntäainetta säilötyt ja 4) loput, todettiin ryhmien $1-2$ ja $3-4$ välillä suuria eroja koostumuksen huononemisessa, ME-arvon laskussa ja säilöntätappioissa $(\mathrm{P}<$ 0.01-0.001). Päältä valuva mehu oli pahempi kuin korjuu sateella.

Suuret ka-tappiot ja rehun energia-arvon lasku liittyivät kiinteästi yhteen. Keskimääräinen orgaanisen aineen in vitro -sulavuuden lasku oli $3.7 \%$ ja ME-arvon lasku $3.5 \%$. Raakaproteinipitoisuuteen tappiot vaikuttivat hyvin vähän, koska kuiva-aine- ja proteiinitappiot olivat saman suuruisia. Suuriin tappioihin liittyi rehun heikko laatu.

1. korjuukerran ruoho ja vastaava säilörehu oli sulavuudeltaan ja MEarvoltaan muita parempaa. Käyminen oli siinä merkitsevästi $(\mathrm{P}<0.001)$ voimakkaampaa kuin 3 . korjuun rehussa, vaikka vesipitoisuus oli viimeksimainitussa korkeampi.

Vuosia vertailtaessa säilöntätulokseen vaikutti eniten ruohon kuiva-ainepitoisuus säilöttäessä ja korjuuajan sateisuus. Sadekesän 1972 rehu oli ravintoarvoltaan ja laadultaan muita heikompaa.

Ruohon ja vastaavan säilörehun monien aineosien välillä todettiin kiinteitä korrelaatioita, samoin eri koostumusmuutosten ja tappioiden välillä.

Säilöntätulosten hajonta osoittautui käytännön säilörehun valmistuksessa huomattavasti suuremmaksi, mitä järjestetyissä koe-oloissa tapahtuu. Yli kolmanneksella näytteistä kuiva-ainetappiot olivat alle $5 \%$ ja kymmenellä prosentilla yli $25 \%$. Pahimmat virheet säilörehun teossa olivat seuraavat: 1) Sateen sattuessa säilörehun tekoa jatkettiin samaan siiloon, jolloin esikuivatun päälle tuli sateen kastelemaa esikuivattua tai niittotuoretta. 2) Syksyllä pantiin entisen rehun päälle niittotuoretta ruohoa tai peräti naatteja. Saumaamaton muovikalvo oli välissä, mutta se ei estänyt puristemehua valumasta rehuun. Toisaalta, sateen kastelemastakin ruohosta - myös lyhyen aikaa esikuivatusta - saatiin hyvä tulos silloin, kun se ajettiin siilon pohjalle ja päälle tuli painoksi niin kuivaa ruohoa, ettei siitä valunut mehua. 
Aerts, J. V., Brabander, D. L. de, Cotryn, B. G. \& Buysse, F. X. 1974. A practical system for evaluation of the nutritive value of roughages based on the crude components. Proc. 5th Gen. Meet. Eur. Grassl. Fed. Uppsala: 7-11.

A. O. A. C. 1960. Official methods of analysis of the association of official agricultural chemists. 832 p. Washington.

Ettala, E., Lampila, M., Huida, L., Huokuna, E. \& Ронјanheimo, O. 1971 . Valkuaisrikkaiden nurmisäilörehujen laatu ja koostumus. Kehittyvä maatalous $3: 3-14$.

— - ,Nenonen, E. \& LAmpILA, M. 1972. Nurmisäilörehujen säilöntätappioista. Kehittyvã maatalous 7: 16-28.

— - , Ронјаnheimo, O., Huida, L., \& Lampila, M. 1975. Hapot sekä hapon ja formaldehydin seokset ruohon säilönnässä. Kotieläinhoidon tutkimuslaitoksen tiedote n:o 1: $1-27$.

Gordon, C. H., Derbyshire, J. C., Wiseman, H. G. \& Jacobson, W. C. 1964. Variations in initial composition of orchard grass as related to silage composition and feeding value. J. Dairy Sci. 47: $987-992$.

Gross, F. 1975. Gebräuchliche Seliermittel im vergleich. Wirtschaftseig. Futter 21: 42-52.

- - \& Averdunk, G. 1968. Uber die Trockensubstanzverluste beim Silieren eiweissreicher Futtermittel. Wirtschaftseig. Futter 14: 194-205.

- - \& Riebe, K. 1974. Gärfutter, 283 p. Stuttgart.

HAgemeister, H. 1967. Untersuchungen über Verluste bei der Gärheu-, Frischgras- und Mischsilage Bereitung sowie über den Silageverzehr. Wirtschaftseig. Futter 13: $316-328$.

Henderson, A. R., McDonald, P. \& Woolford, M. K. 1972. Chemical changes and losses during the ensilage of wilted grass treated with formic acid. J. Sci. Food Agric. 23: $1079-1087$.

JAckson, N. \& Anderson, B. K. 1968. Conservation of fresh and wilted grass in airtight metal containers. J. Sci. Food Agric. 19: 1-4.

Maskova, H. \& Havelik, J. 1969. Gärverlauf und Verluste in Hochsilos. Wirtschaftseig. Futter 15: 165-184.

McDonald, P., Henderson, A. R. \& MacGregor, A. W. 1968. Chemical changes and losses during the ensilage of wilted grass. J. Sci. Food Agric. 19: 125-132.

NJF. Fodermiddeltabel. 1969. 40 p. Gjøvik.

Poutiarnen, E. \& Rinne, K. 1971. Korjuuasteen vaikutus säilörehun ravintoarvoon. Kehittyvä maatalous $3: 15-28$.

SALO, M.-L. 1965. Determination of carbohydrate fractions in animal foods and faeces. Acta Agr. Fenn. 105: 1-102.

- - \& Kotilainen, K. 1969. Determination of free and combined plant acids. J. Scient. Agric. Soc. Finl. 41: 277-289.

- - \& Sormunen, R. 1974. Sokerijuurikkaan naatit ja niistä valmistettu säilörehu. J. Scient. Agric. Soc. Finl. 46: 97-102.

Skovborg, E. B. \& Andersen, P. E. 1973. Konserverede graesmarksafgroder til malkekoer II. 4. Ber. Stat. Planteavls Husdyrbrugsforsøg: 1-46.

Terry, R. A., Osbourn, D. F., Cammell, S. B. \& Fenlon, J. S. 1974. In vitro digestibility and the estimation of energy in herbage. Proc. 5th Gen. Meet. Eur. Grassl. Fed. Uppsala: 19-25.

Tilley, J. M. A. \& TerRy, R. A. 1963. A two-stage technique for the in vitro digestion of forage crops. J. Brit. Grassl. Soc. 18: 104-111.

WEISE, F. \& HoNIG, H. 1975. Einfluss unterschiedlicher Vorwelkzeiten auf den Gärverlauf bei Wiesenschwingel. Wirtschaftseig. Futter 21:10-24.

Vuyst, A. de, Arnould, R., Vanbelle, M. \& Deswysen, A. 1975. Untersuchungen über Seliermittel. Wirtschaftseig. Futter 21:33-41.

Käsikirjoitus saapunut 7.6.1975. 